\title{
Review of some biological aspects and fisheries of grey-eel catfish Plotosus canius
}

(Hamilton, 1822)

\begin{abstract}
Plotosus canius, the grey-eel catfish belonging to the family Plotosidae is endemic to the south-east Asia and Australia. Primarily the fish is found in marine environment but at times may be found in brackish or fresh water environments. Despite the vast research that have been conducted on various catfish species, both marine and freshwater; little attention has been paid to P. canius. This study reviewed published information on the distribution, biology and fisheries of this economically important fish species.
\end{abstract}

Keyword: Fish biology; Fisheries; Grey-eel catfish; Marine environment; Plotosus canius 